\title{
Lead(II) retention by Alfisol and clinoptilolite: cation balance and $\mathrm{pH}$ effect
}

\author{
Alexander A. Ponizovsky ${ }^{\mathrm{a}, \mathrm{b}, *}$, Christos D. Tsadilas ${ }^{\mathrm{c}}$ \\ ${ }^{a}$ Institute of Physical, Chemical, and Biological Problems in Soil Science, Russian Academy of Sciences, \\ Pushchino 142290, Moscow Region, Russia \\ ${ }^{\mathrm{b}}$ Department of Civil and Environmental Engineering, University of Delaware, DuPont Hall, \\ Academy St., Newark, DE 19716, USA \\ ${ }^{\mathrm{c}}$ Institute of Soil Classification and Mapping, National Agricultural Research Foundation, \\ Theofrastou 1 Str., Larissa 41335, Greece
}

Received 9 October 2001; accepted 27 January 2003

\begin{abstract}
Lead $\left(\mathrm{Pb}^{2+}\right)$ sorption by Alfisol and zeolite was studied at $\mathrm{pH} 3,4$, and 5 to find the relationship between the amounts of $\mathrm{Pb}$ retained and ions displaced from the soil into the solution. In Alfisol $\mathrm{Pb}$ sorption was accompanied by the increase in contents of both $\mathrm{Ca}^{2+}$ and $\mathrm{H}^{+}$constituting about $2 / 3$ and $1 / 3$ of the total amount of displaced cations, respectively. Increase in $\mathrm{pH}$ enhanced sorption of $\mathrm{Pb}$. Hystersis of lead adsorption was observed in Alfisol. Clinoptilolite zeolite sorbed 20-30 times more $\mathrm{Pb}$ than the soil. Lead sorption by zeolite was not influenced by $\mathrm{pH}$ and was accompanied by the increase of $\mathrm{Ca}^{2+}, \mathrm{Na}^{+}$, and $\mathrm{K}^{+}$contents in solution, whereas amounts of displaced $\mathrm{H}^{+}$were negligible. The research indicates that $\mathrm{Pb}$ retention both by Alfisol and zeolite can be viewed as the result of ion exchange reaction with strong (soil) or very strong (zeolite) specific binding of $\mathrm{Pb}$. Application of zeolite in some instances may appear the most efficient treatment for reclamation of lead-contaminated soils due to its high ability to retain $\mathrm{Pb}$ in a wide range of $\mathrm{pH}$.

(C) 2003 Elsevier Science B.V. All rights reserved.
\end{abstract}

Keywords: Lead in soil; Zeolite; Ion exchange in soils; Sorption of trace elements in soils; Soil remediation

\section{Introduction}

Reducing the availability of trace metals to plants is critical for optimizing agricultural production at the lands contaminated due to military, urban, or industrial

* Corresponding author. Tel.: +7-967-733845.

E-mail address: ponizovsky@yahoo.com (A.A. Ponizovsky). 
use. Decreasing plant uptake of trace metals from soil may enable permissible contaminant levels in crops. Phytoavailability of trace metals correlates best with their concentrations in soil solution rather with their total content in soil (KabataPendias and Brümmer, 1992; Kabata-Pendias and Pendias, 1992). So, it may be reduced if the metals are sorbed or precipitated from the soil solution.

Lead $\left(\mathrm{Pb}^{2+}\right)$ is a widespread soil contaminant that represents a major challenge for soil remediation. One of the most important methods to decrease lead availability to plants is liming which increases soil $\mathrm{pH}$ and enhances $\mathrm{Pb}$ retention in the solid phase (Tsadilas, 2000). Liming has its limitations. It is not efficient in strongly acid soils and large amounts of lime are not available in many regions. Continued influx of acidic water, even slightly acidic rain water, can eventually neutralize the lime and cause $\mathrm{Pb}$ remobilization. Another method to immobilize lead is application of organic fertilizers or phosphates. In particular, solution lead concentration in $\mathrm{Pb}$-enriched soil can be substantially reduced by adding hydroxyapatite $\left[\mathrm{Ca}_{5}\left(\mathrm{PO}_{4}\right)_{3}(\mathrm{OH})\right]$ (Ma et al., 1992; Ma, 1996), monocalcium phosphate $\left[\mathrm{Ca}\left(\mathrm{H}_{2} \mathrm{PO}_{4}\right)_{2} \cdot 2 \mathrm{H}_{2} \mathrm{O}\right]$ (Kalbasi et al., 1995), or $\mathrm{Na}_{2} \mathrm{HPO}_{4}$ (Rabinovitz, 1993). This response is attributed to the precipitation of hydroxypyromorphite $\left[\mathrm{Pb}_{10}\left(\mathrm{PO}_{4}\right)_{6}(\mathrm{OH})_{2}\right]$.

An alternative way to $\mathrm{Pb}$ immobilization may be the application of zeolites (Tsitsishvili et al., 1985; Leppert, 1990). Some zeolites, e.g. clinoptilolite, are stable in acid conditions up to $\mathrm{pH} 2$ (Ming and Mumpton, 1989). High affinity of zeolites to trace metals has been demonstrated (Barrer, 1978; Tarasevich et al., 1997; Tsadilas et al., 1997). Application of zeolites could potentially be an efficient method to immobilize $\mathrm{Pb}$ in soil, and thus decrease lead concentration in the soil solution. However, no quantitative estimates of this effect are available in the literature.

Lead retention in soils is commonly attributed to the ion exchange or specific sorption on silicates, metal oxide-hydroxides, and organic matter (Kabata-Pendias and Pendias, 1992; Tills and Alloway, 1983; Sauvé et al., 2000), penetration of $\mathrm{Pb}$ ions in the interlayer space of clay minerals (Zyrin et al., 1986), as well as precipitation of $\mathrm{Pb}$ minerals. Processes causing lead retention may be distinguished by comparing amount of retained $\mathrm{Pb}$ and amount of ions displaced from the soil surface into soil solution (Ponizovsky and Mironenko, 2001a). A process may be called cation exchange when some cations are displaced into solution in the amount equal to the amount of $\mathrm{Pb}^{2+}$ retained in solid phases. If $\mathrm{Pb}^{2+}$ is removed from solution into solid phase without displacement of any cations into solution or removal of equal amount of anions, the process should be referred as adsorption. Adsorption of ions should cause changes in the surface charge of soil particles (Bolt et al., 1978). Precipitation of sparingly soluble salts or lead hydroxide is accompanied by the simultaneous removal of some anions from the solution and no sorbed cations are displaced. Thus, a comparison between amount of retained lead and amounts of cations appearing in solution can provide information about the mechanism of immobilization of this trace metal in soil.

The objective of this study was to use the cation balance to infer a mechanism of $\mathrm{Pb}$ retention in Alfisol soil and in zeolite mineral. 


\section{Materials and methods}

\subsection{Soil and zeolite properties}

The study was carried out on a sandy loam Alfisol (Typic Rhodoxeralf, $A_{p}$ horizon) from Magnesia (Central Greece), and clinoptilolite zeolite from 'Beli Plast' mine (Bulgaria). Selected properties of the soil and zeolite are presented in Table 1. The soil was slightly acid with low contents of organic matter and phosphorus. The zeolite contained 70.1\% $\mathrm{SiO}_{2}, 11.4 \% \mathrm{Al}_{2} \mathrm{O}_{3}, 0.78 \% \mathrm{Fe}_{2} \mathrm{O}_{3}, 0.13 \% \mathrm{TiO}_{2}, 2.95 \% \mathrm{CaO}, 0.37 \%$ $\mathrm{MgO}, 0.70 \% \mathrm{Na}_{2} \mathrm{O}$, and $3.30 \% \mathrm{~K}_{2} \mathrm{O}$, while loss on ignition was $10.2 \%$. A description of the methods used to estimate zeolite composition along with some additional data on the chemical properties of the zeolite from the same mine can be found elsewhere (Tarasevich et al., 1997).

\subsection{Equilibrium of $\mathrm{Pb}$ retention by soil and zeolite}

In order to determine the time necessary to obtain $\mathrm{Pb}$ sorption equilibrium, 4-g samples were suspended in $75 \mathrm{ml}$ of $3 \mathrm{mM} \mathrm{Ca}\left(\mathrm{NO}_{3}\right)_{2}$ solution. One milliliter of $0.05 \mathrm{M} \mathrm{Pb}\left(\mathrm{NO}_{3}\right)_{2}$ solution was added and the $\mathrm{pH}$ adjusted to 3,4 , and 5 by adding $0.1 \mathrm{M} \mathrm{HNO}_{3}$ or $0.01 \mathrm{M}$ $\mathrm{KOH}$ as necessary. The suspensions were shaken at $25 \pm 1{ }^{\circ} \mathrm{C}$ using an end-to-end shaker. After 1, 3, 5, 10, 24, 72, and $120 \mathrm{~h}$ the suspensions were allowed to settle for $1 \mathrm{~h}$ and solutions were sampled. The samples were filtered through a $0.2-\mu \mathrm{m}$ membrane filter and lead concentration was measured with atomic absorption spectroscopy. The solution $\mathrm{pH}$ was monitored in the same intervals and adjusted to the initial values by titration with 0.1 $\mathrm{M} \mathrm{HNO}_{3}$ or $0.05 \mathrm{M} \mathrm{KOH}$. Sorbed $\mathrm{Pb}$ amount was calculated as the difference between the amount of $\mathrm{Pb}$ added and the amount recovered in the supernatant solutions. The period necessary to obtain constant $\mathrm{Pb}$ concentration in the solution was used as the time required to obtain sorption equilibrium in subsequent experiments.

\subsection{Lead retention isotherms}

The batch sorption isotherm study was conducted according to the procedure similar to that described by Ponizovsky et al. (2001). Four-gram soil samples were suspended in 50 $\mathrm{ml}$ of $3 \mathrm{mM} \mathrm{Ca}\left(\mathrm{NO}_{3}\right)_{2}$ background solution in $100 \mathrm{ml}$ conic flasks. From 0.5 to $10 \mathrm{ml}$ of $25 \mathrm{mM} \mathrm{Pb}\left(\mathrm{NO}_{3}\right)_{2}$ were then added. An additional suspension, without $\mathrm{Pb}\left(\mathrm{NO}_{3}\right)_{2}$, was taken as a control. The $\mathrm{pH}$ was adjusted to 3,4 , or 5 by adding $0.05 \mathrm{M} \mathrm{HNO}_{3}$ or $0.04 \mathrm{M}$ $\mathrm{KOH}$, and the samples were shaken at $25 \pm 1{ }^{\circ} \mathrm{C}$ for 2 days. The $\mathrm{pH}$ was re-adjusted in $2 \mathrm{~h}$ and 1 day by titration with $\mathrm{HNO}_{3}$ or $\mathrm{KOH}$. The suspensions were centrifuged and supernatant solutions were sampled. Samples were filtered through $0.2-\mu \mathrm{m}$ membrane filter.

$\mathrm{Pb}, \mathrm{Ca}$, and $\mathrm{Mg}$ were determined in supernatant solutions with atomic absorption spectroscopy. Concentrations of $\mathrm{K}$ and $\mathrm{Na}$ were measured by flame photometry. The amount of $\mathrm{Pb}$ retained was estimated as the difference between the $\mathrm{Pb}$ added and that remaining in solution at equilibrium basing on measured concentrations and actual volumes of the solutions. The amounts of $\mathrm{Ca}, \mathrm{K}$, and $\mathrm{Na}$ displaced by $\mathrm{Pb}$ were calculated 
Table 1

Selected properties of soil and zeolite

\begin{tabular}{llllllllllll}
\hline Sample & $\begin{array}{l}\mathrm{pH} \\
\left(\mathrm{H}_{2} \mathrm{O}\right)\end{array}$ & $\begin{array}{l}\text { Organic } \\
\text { matter } \\
(\%)\end{array}$ & $\begin{array}{l}\mathrm{P}^{\mathrm{a}} \\
\left(\mathrm{mg} \mathrm{kg}{ }^{-1}\right)\end{array}$ & $\begin{array}{l}\text { Clay } \\
(\%)\end{array}$ & $\begin{array}{l}\text { Silt } \\
(\%)\end{array}$ & $\begin{array}{l}\text { Sand } \\
(\%)\end{array}$ & $\begin{array}{l}\mathrm{CEC} \\
\left(\mathrm{cmol}(+) \mathrm{kg}^{-1}\right)\end{array}$ & $\begin{array}{l}\text { Exchangeable cations } \\
\mathrm{K}^{+} \\
\left(\mathrm{cmol}(+) \mathrm{kg}^{-1}\right)\end{array}$ & $\begin{array}{l}\mathrm{Na}^{+} \\
\left(\mathrm{cmol}^{\mathrm{b}}+\mathrm{kg}^{-1}\right)\end{array}$ & $\begin{array}{l}\mathrm{Ca}^{2+} \\
\left(\mathrm{cmol}^{2+}+\mathrm{kg}^{-1}\right)\end{array}$ & $\begin{array}{l}\mathrm{Mg}^{2+} \\
\left.\left(\mathrm{cmol}^{+}+\right) \mathrm{kg}^{-1}\right)\end{array}$ \\
\hline Soil & 5.67 & 0.84 & 5.15 & 18 & 30 & 52 & $7.39^{\mathrm{c}}$ & 0.32 & 0.08 & 3.57 & 0.29 \\
Zeolite & 7.65 & - & - & - & - & - & $118^{\mathrm{b}}$ & 33.4 & 16.9 & 64.8 & 2.69 \\
\hline
\end{tabular}

${ }^{\mathrm{a}}$ Extraction with $0.5 \mathrm{M} \mathrm{NaHCO}_{3}, \mathrm{pH} 8.5$, according to Olsen et al. (1954) method.

${ }^{\mathrm{b}} \mathrm{NH}_{4} \mathrm{OAc}, \mathrm{pH}$ 7.0.

${ }^{\mathrm{c}} \mathrm{NaOAc}, \mathrm{pH}$ 8.2. 
as the differences between the amounts found in the supernatant solution of the suspension with added $\mathrm{Pb}\left(\mathrm{NO}_{3}\right)_{2}$ and in the control with the same $\mathrm{pH}$ without $\mathrm{Pb}\left(\mathrm{NO}_{3}\right)_{2}$. The amount of $\mathrm{H}^{+}$displaced from the soil due to $\mathrm{Pb}^{2+}$ sorption was calculated from the amounts of $\mathrm{HNO}_{3}$ or $\mathrm{KOH}$ used to adjust $\mathrm{pH}$.

To determine $\mathrm{Pb}$ desorption from the treated samples, the residues obtained after centrifugation were transferred from the centrifuge flasks with $50 \mathrm{ml}$ of $3 \mathrm{mM} \mathrm{Ca}\left(\mathrm{NO}_{3}\right)_{2}$ solution to $100 \mathrm{ml}$ conic flasks. Then $\mathrm{pH}$ was adjusted and suspensions were mixed as mentioned above. After 2 days, the suspensions were centrifuged, and the samples of supernatant solutions were filtered and analyzed.

Isotherms of $\mathrm{Pb}$ sorption by zeolite were obtained with the same procedure differed only in using 2-g samples suspended in the background solution, and adding of more concentrated $200 \mathrm{mM} \mathrm{Pb}\left(\mathrm{NO}_{3}\right)_{2}$ in the amounts of $0,0.5,1,2,3$, and $5 \mathrm{ml}$. More concentrated $\mathrm{Pb}\left(\mathrm{NO}_{3}\right)_{2}$ was applied since zeolite strongly sorbed $\mathrm{Pb}$ decreasing solution concentration up to the levels close to detection limit of atomic absorption spectroscopy. The above amounts of $\mathrm{Pb}\left(\mathrm{NO}_{3}\right)_{2}$ added enabled to obtain $\mathrm{Pb}$ concentrations in the equilibrium solution close to those observed in soil suspensions with additions of 25 $\mathrm{mM} \mathrm{Pb}\left(\mathrm{NO}_{3}\right)_{2}$.

Chemical equilibrium calculations were performed using RAME software (Mironenko et al., 1996) with constants compiled by Sauvé et al. (1998).

\section{Results}

Only a minor increase in $\mathrm{Pb}$ retention was observed in soil suspensions shaken at constant $\mathrm{pH}$ after $48 \mathrm{~h}$ for the subsequent period up to $120 \mathrm{~h}$. The sorption rate was highest at $\mathrm{pH} 5$ (approximately $95 \%$ of the maximal $\mathrm{Pb}$ retention was observed in $2 \mathrm{~h}$ ) and lowest at $\mathrm{pH}$ 3. In zeolite suspensions constant $\mathrm{Pb}$ level in the solutions was attained in $2 \mathrm{~h}$. So, the period of $48 \mathrm{~h}$ was taken as sufficient to obtain quasi-equilibrium in all experiments.

Isotherms of $\mathrm{Pb}$ sorption and desorption by soil at $\mathrm{pH} \mathrm{3,4}$, and 5 are presented in Fig. $1 \mathrm{a}-\mathrm{c}$. The data are approximated by the Freundlich equation:

$$
S_{\mathrm{Pb}}=K\left(m_{\mathrm{Pb}}\right)^{\alpha}
$$

where $S_{\mathrm{Pb}}$ and $m_{\mathrm{Pb}}$ are amount of lead(II) sorbed (mmol kg ${ }^{-1}$ ) and $\mathrm{Pb}$ concentration (mmol $1^{-1}$ ) in the equilibrium solution, respectively; $K$ and $\alpha$ are constants.

Higher $\mathrm{pH}$ enhanced sorption of $\mathrm{Pb}$. Lead retention by soil was accompanied by the displacement of both $\mathrm{Ca}^{2+}$ and $\mathrm{H}^{+}$cations while the amounts of $\mathrm{K}^{+}, \mathrm{Na}^{+}$, and $\mathrm{Mg}^{2+}$ displaced were negligible (Fig. 1d-f). Linear regression was fitted to the data on the relationships between the amounts of displaced cations and sorbed $\mathrm{Pb}$. Correlation coefficients of the regressions were $0.84-0.95$. The slope of each regression equation is an estimate of the mean quantity of the ion displaced by 1 mol of lead. The obtained values together with their standard deviations for all the displaced ions are presented in Table 2. Such estimation of the amounts of $\mathrm{H}^{+}, \mathrm{Ca}^{2+}, \mathrm{K}^{+}, \mathrm{Na}^{+}$, and $\mathrm{Mg}^{2+}$ displaced from the soil by $\mathrm{Pb}$ is unaffected by acid-base buffer ability of soil and minerals dissolution since the starting point of linear regression is the value obtained in the blank without any addition of $\mathrm{Pb}$ but with the identical $\mathrm{pH}$ value (Ponizovsky et al., 2001). 
pH 3
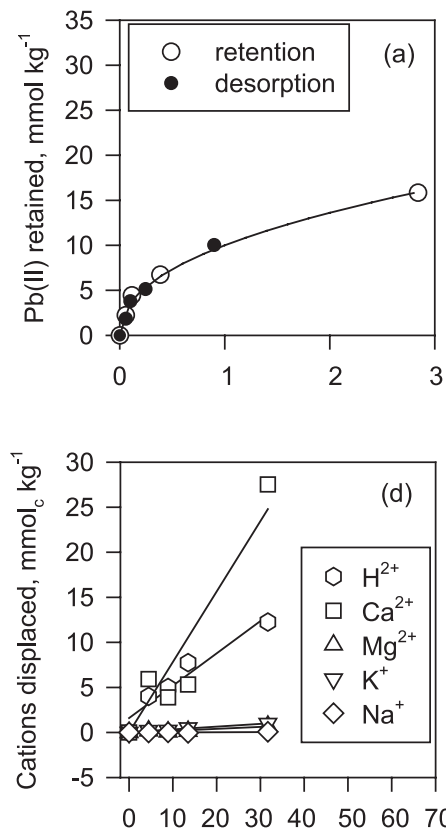

pH 4

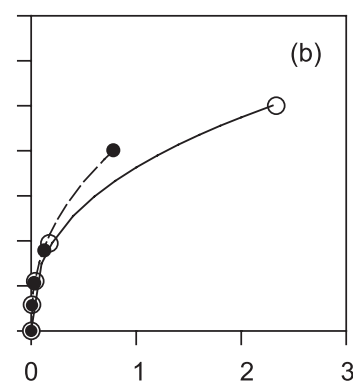

$\mathrm{Pb}(\mathrm{II}), \mathrm{mmol} \mathrm{L}^{-1}$

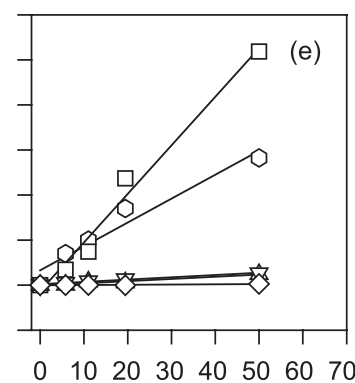

$\mathrm{Pb}(\mathrm{II})$ retained, $\mathrm{mmol}_{\mathrm{c}} \mathrm{kg}^{-1}$
pH 5
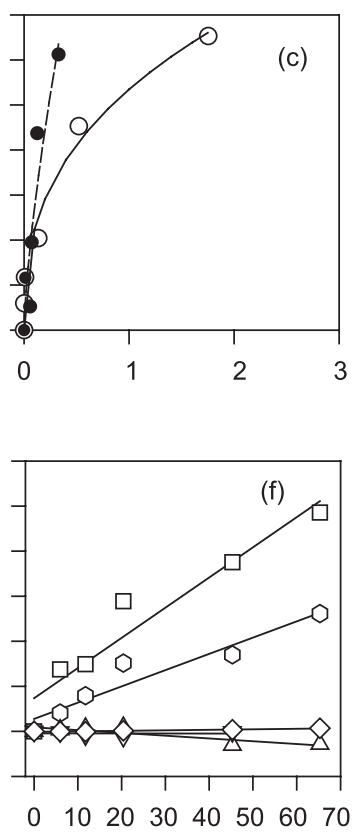

Fig. 1. Isotherms $25{ }^{\circ} \mathrm{C}$ of lead(II) retention by soil at pH 3 (a), 4 (b), and 5 (c) (lines - calculated with Freundlich equation), and dependences of the amounts of replaced cations on the amount of $\mathrm{Pb}$ (II) retained at the same $\mathrm{pH}$ values (d, e, and $\mathrm{f}$, respectively).

As can be seen from Table 2, for each $\mathrm{pH}$ the sum of mean amounts of all the displaced cations per $\mathrm{mol}(+)$ of $\mathrm{Pb}$ retained was close to 1 . The observed differences from 1 were statistically insignificant ( $t$-test, $P=0.05$ ) and can be attributed to analytical errors. Thus, the amount of displaced ions was close to the amount retained.

Table 2

Amounts of cations displaced per $\operatorname{mol}_{\mathrm{c}}$ of lead(II) retained by soil and zeolite (mean \pm S.D.)

\begin{tabular}{llllllll}
\hline Sample & $\mathrm{pH}$ & \multicolumn{2}{l}{ Ions displaced } & & & \\
\cline { 3 - 8 } & & $\begin{array}{l}\mathrm{K}^{+} \\
(\mathrm{mol}(+)\end{array}$ & $\begin{array}{l}\mathrm{Na}^{+} \\
(\mathrm{mol}(+)\end{array}$ & $\begin{array}{l}\mathrm{Mg}^{2+} \\
(\mathrm{mol}(+) \\
\left.\mathrm{mol}(+)^{-1}\right)\end{array}$ & $\begin{array}{l}\mathrm{Ca}^{2+} \\
(\mathrm{mol}(+) \\
\left.\mathrm{mol}(+)^{-1}\right)\end{array}$ & $\begin{array}{l}\mathrm{H}^{+} \\
(\mathrm{mol}(+) \\
\left.\mathrm{mol}(+)^{-1}\right)\end{array}$ & $\begin{array}{l}\begin{array}{l}\Sigma \mathrm{Kt}^{\mathrm{a}} \\
(\mathrm{mol}(+)\end{array} \\
\left.\mathrm{mol}^{-1}(+)^{-1}\right)\end{array}$ \\
\hline Soil & 3 & $0.03 \pm 0.005$ & $0.002 \pm 0.001$ & $0.02 \pm 0.005$ & $0.78 \pm 0.16$ & $0.36 \pm 0.06$ & $1.19 \pm 0.16$ \\
& 4 & $0.03 \pm 0.002$ & $0.003 \pm 0.001$ & $0.02 \pm 0.003$ & $0.64 \pm 0.04$ & $0.27 \pm 0.04$ & $0.96 \pm 0.06$ \\
& 5 & $0.002 \pm 0.007$ & $0.01 \pm 0.002$ & $0.05 \pm 0.018$ & $0.67 \pm 0.10$ & $0.36 \pm 0.06$ & $0.99 \pm 0.15$ \\
Zeolite & 3 & $0.08 \pm 0.006$ & $0.09 \pm 0.009$ & $0.04 \pm 0.0001$ & $0.65 \pm 0.03$ & $0.04 \pm 0.006$ & $0.90 \pm 0.02$ \\
& 4 & $0.18 \pm 0.01$ & $0.15 \pm 0.017$ & $0.03 \pm 0.002$ & $0.71 \pm 0.09$ & $0.02 \pm 0.003$ & $1.00 \pm 0.07$ \\
& 5 & $0.08 \pm 0.007$ & $0.21 \pm 0.04$ & $0.03 \pm 0.003$ & $0.67 \pm 0.05$ & $0.03 \pm 0.002$ & $1.01 \pm 0.05$ \\
\hline
\end{tabular}

${ }^{\text {a }}$ Sum of displaced cations. 

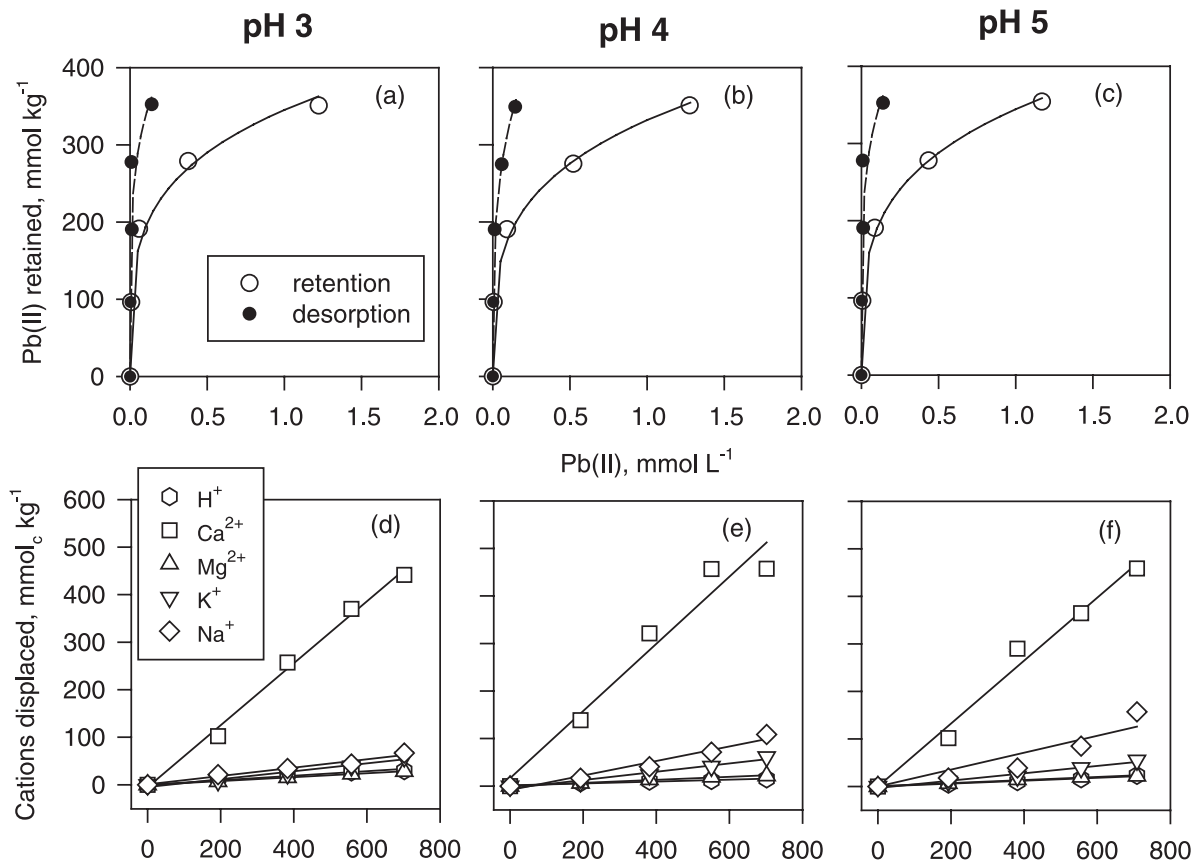

$\mathrm{Pb}(\mathrm{II}), \mathrm{mmol} \mathrm{L}^{-1}$
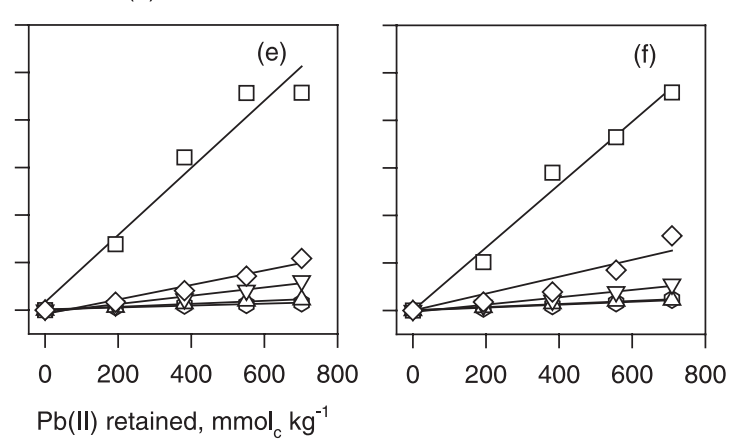

Fig. 2. Isotherms $25{ }^{\circ} \mathrm{C}$ of lead(II) retention by zeolite at $\mathrm{pH} 3$ (a), 4 (b), and 5 (c) (lines-calculated with Freundlich equation), and dependences of the amounts of replaced cations on the amount of $\mathrm{Pb}$ (II) retained at the same $\mathrm{pH}$ values (d, e, and $\mathrm{f}$, respectively).

Clinoptilolite sorbed much more $\mathrm{Pb}$ than soil and the sorbed amount was independent of $\mathrm{pH}$ (Fig. 2a-c). The retention was accompanied by displacement mainly of $\mathrm{Ca}^{2+}$ and small amounts of $\mathrm{K}^{+}$and $\mathrm{Na}^{+}$cations (Fig. $2 \mathrm{~d}-\mathrm{f}$ ). The amounts of displaced $\mathrm{H}^{+}$and $\mathrm{Mg}^{2+}$ were negligible (Table 2). The sums of the displaced cations were close to the amount of $\mathrm{Pb}$ retained. Treatment of $\mathrm{Pb}$-containing zeolite with $\mathrm{Ca}\left(\mathrm{NO}_{3}\right)_{2}$ solution did not result in any significant desorption of $\mathrm{Pb}$ (II).

Maximal sorption capacity of zeolite calculated based on the data presented in Fig. 2 using Langmuir adsorption equation (Alloway, 1995) appeared to be $360 \mathrm{mmol} \mathrm{kg}^{-1}$.

\section{Discussion}

Lead retention in our experiments was not caused by precipitation of slightly soluble $\mathrm{Pb}$ salts. Lead carbonate $\mathrm{PbCO}_{3}$ and base carbonate $3 \mathrm{~Pb}\left(\mathrm{CO}_{3}\right)_{2} \cdot 2 \mathrm{~Pb}(\mathrm{OH})_{2}$ are the least soluble salts of $\mathrm{Pb}$ besides sulfide and chloropyromorphite. Both carbonates precipitate only in alkali range of $\mathrm{pH}$ (Gmelins Handbook, 1961). Calculations based on the solubility constants of these salts using the RAME software (Mironenko et al., 1996) revealed that solutions used in this study were undersaturated with respect to both of these salts. Surface precipitation of them on the surface of soil particles can be also excluded due to the 
extremely low concentrations of $\mathrm{OH}^{-}$and $\mathrm{CO}_{3}^{2-}$ ions at $\mathrm{pH} 3-5$. Total content of phosphate in the soil samples $\left(5.15 \mathrm{ppm}\right.$ or $\left.0.17 \mathrm{mmol} \mathrm{kg}^{-1}\right)$ was much lower than the amount of sorbed $\mathrm{Pb}$, so $\mathrm{Pb}$ was not retained due to precipitation of chloropyromorphite.

Based on the balance between sorbed and displaced ions, $\mathrm{Pb}$ sorption may be considered as an ion exchange since it is accompanied by the displacement of ions and the amounts of retained $\mathrm{Pb}$ and displaced cations are equivalent. So, it is not necessary to speculate about some changes in the surface charge or sorption of charged complexes. The exchange is not binary and involves three cations, namely $\left(\mathrm{H}^{+}+\mathrm{Ca}^{2+}\right)-\mathrm{Pb}^{2+}$ at all the $\mathrm{pH}$ values. The ratio between the amounts of $\mathrm{H}^{+}$and $\mathrm{Ca}^{2+}$ displaced per $\mathrm{mol}(+) \mathrm{Pb}^{2+}$ retained at all the $\mathrm{pH}$ values studied is close to $1 / 2$ (Table 2). Similar results were obtained for lead retention on Chernozem, Dernovo-Podzolic, and Gray Forest soils (Ponizovsky and Mironenko, 2001b). Copper(II) sorption by soils is also accompanied by simultaneous displacement of these two cations (Ponizovsky et al., 2001). Displacement of $\mathrm{H}^{+}$ions may be a common phenomenon for the retention of trace metals in the soils.

Some hysteresis between sorption and desorption isotherms is observed in Fig. 1a-c. It increases with the increase in solution $\mathrm{pH}$. This hysteresis may be attributed to the different rates of sorption and desorption processes as it was suggested by Strawn and Sparks (2000), assuming that 2-day period may be not sufficient to attain complete desorption equilibrium. Sorbate may undergo some transformation and being transformed may slower interact with the species in the solution. The composition and properties of forming surface complex may be affected by solution $\mathrm{pH}$.

Clinoptilolite sorbed 10-20 times more $\mathrm{Pb}$ than the same mass of soil, and only a small portion of $\mathrm{Pb}$ was released while the treated sample was exposed to fresh $\mathrm{Pb}$-free background solution. Lead sorption by zeolite was accompanied by the release of mainly $\mathrm{Ca}^{2+}$ and minor amounts of $\mathrm{Na}^{+}$and $\mathrm{K}^{+}$. The process was irreversible or with a very strongly emphasized hysteresis (Fig. $2 \mathrm{a}-\mathrm{c}$ ). Cation exchange capacity of clinoptilolite is about 16 times larger than that of the soil (Table 1). However, not only the quantity of the element sorbed but the sorption mechanism is very different: zeolite strongly binds $\mathrm{Pb}^{2+}$ ions within the crystal (Barrer, 1978; Tarasevich et al., 1997).

Sorption is independent on $\mathrm{pH}$ for zeolite where we did not observe any displacement of $\mathrm{H}^{+}$. So, the impact of $\mathrm{pH}$ on $\mathrm{Pb}$ retention may be attributed to the shift of $\mathrm{H}^{+}-\mathrm{Pb}^{2+}$ exchange equilibrium.

Application of zeolite leads to a decrease of $\mathrm{Pb}$ concentrations in soil solution retaining the metal in the solid phase, where it should be less available for plants. Calculations basing on the value of maximal sorption capacity of zeolite reveal that $1 \%$ added zeolite can retain $3.6 \mathrm{mmol} \mathrm{Pb} \mathrm{kg}^{-1}$ or $750 \mathrm{mg} \mathrm{kg}^{-1}$ soil. Advantage of zeolite for soil amelioration is its high efficiency independent on soil $\mathrm{pH}$ in the $\mathrm{pH}$ range 3-5.

A practical consequence of the dependence of sorbed $\mathrm{Pb}$ on solution $\mathrm{pH}$ is the necessity to stabilize this parameter while obtaining sorption isotherms.

\section{Conclusions}

Lead sorption by Alfisol is accompanied by simultaneous displacement in the solution of both $\mathrm{Ca}^{2+}$ and $\mathrm{H}^{+}$in the amounts close to the quantities of $\mathrm{Pb}$ sorbed. So, the process 
may be assumed as a three-cation ion exchange. Hysteresis between sorption and desorption isotherms obtained within a 2-day shaking of soil-solution suspensions increased with the increase in $\mathrm{pH}$. Clinoptilolite zeolite sorbed $\mathrm{Pb}$ in the amounts about 20-30 times higher than the soil. Lead sorption by zeolite was accompanied by the displacement mainly of $\mathrm{Ca}^{2+}$ and minor amounts of $\mathrm{Na}^{+}$and $\mathrm{K}^{+}$. Lead sorbed by zeolite could not be displaced by the applied low concentrations of $\mathrm{Ca}^{2+}$ in batch experiments. The results indicate that $\mathrm{Pb}$ retention by both Alfisol and zeolite may be assumed as an ion exchange process with strong (soil) or very strong (zeolite) specific binding of $\mathrm{Pb}$.

\section{Acknowledgements}

This research was financed by the NATO Fellowship Program and the Russian Foundation on Basic Research (grant no. 00-04-48427). The authors are grateful to the Greek Ministry of National Economy, the National Agricultural Research Foundation of Greece, and the Institute of Physical, Chemical, and Biological Problems of Soil Science of Russian Academy of Sciences for their support in accomplishing this research. The comments of anonymous reviewer were very helpful and are greatly appreciated.

\section{References}

Alloway, B.J., 1995. Soil processes and the behaviour of metals. In: Alloway, B.J. (Ed.), Heavy Metals in Soils, 2nd ed. Blackie Academic \& Professional, Glasgow, pp. 11-37.

Barrer, R.M., 1978. Zeolites and Clay Minerals as Sorbents and Molecular Sieves Academic Press, New York. $497 \mathrm{pp}$.

Bolt, G.H., Bruggenwert, M.G.M., Kamphorst, A., 1978. Adsorption of cations by soil. In: Bolt, G.H., Bruggenwert, M.G.M. (Eds.), Soil Chemistry. B. Basic Elements. Elsevier, Amsterdam, pp. 54-90.

Gmelins Handbuch der anorganischen Chemie, 1961. 8. Auflage. B.47. Teil C 4. Lieferung 1. S.200, Lieferung 2. S. 704. (Ge).

Kabata-Pendias, A., Brümmer, G.W., 1992. Ecological consequences of As, Cd, Hg, and Pb enrichment in European soils. In: Hutchinson, T.C., Meema, K., Gordon, K. (Eds.), Global Perspectives on Lead, Mercury, and Cadmium Cycling in Environment. Wiley Eastern, New Delhi, pp. 107-114.

Kabata-Pendias, A., Pendias, H., 1992. Trace Elements in Soils and Plants CRC Press, London. 365 pp.

Kalbasi, M., Peryea, F.J., Lindsay, W.L., Drake, S.R., 1995. Measurement of divalent lead activity in lead arsenate contaminated soils. Soil Sci. Soc. Am. J. 59, 1274-1280.

Leppert, D., 1990. Heavy metal sorption with clinoptilolite zeolite: alternatives for treating contaminated soil and water. Min. Eng. 42, 604-608.

Ma, L.Q., 1996. Factors influencing the effectiveness and stability of aqueous lead immobilization by hydroxyapatite. J. Environ. Qual. 25, 1420-1429.

Ma, Q.Y., Traina, S.J., Logan, T.J., 1992. Effects of ligands on hydroxiapatite-induced immobilization of aqueous $\mathrm{Pb}$. Agronomy Abstracts. ASA, Madison, p. 47.

Ming, D.W., Mumpton, F.A., 1989. Zeolites in soils. In: Dixon, J.B., Weed, S.B. (Eds.), Minerals in Soil Environment, 2nd ed.SSSA Book Series, pp. 874-911. Madison, WI.

Mironenko, E., Ponizovsky, A., Studenikina, T.A., 1996. Chemical equilibrium model in soils containing heavy metals, low-molecular weight organic acids and fulvic acids. Heavy Metals in the Environment, International Symposium, Pushchino, Russia, pp. 153-154. Ru.

Olsen, S.R., Cole, C.V., Watanabe, F.S., Dean, L.A., 1954. Estimation of available phosphorus in soils by extraction with sodium bicarbonate. USDA Circ., vol. 939. US Gov. Print. Office, Washington, DC. 
Ponizovsky, A., Mironenko, E., 2001a. Speciation and sorption of lead(II) in soils. In: Iskandar, I.K., Kirkham, M.B. (Eds.), Trace Elements in Soil: Bioavailability, Flux, and Transfer. CRC Press, pp. 257-275.

Ponizovsky, A., Mironenko, E., 2001b. Lead(II) retention by soils at pH 4 to 6. Pochvovyedeniye, $25-34$ (Ru). Ponizovsky, A.A., Studenikina, T.A., Mironenko, E.V., Kingery, W.L., 2001. Copper(II) retention by Chernozem, Dernovo-Podzolic, and Gray Forest soils: $\mathrm{pH}$ effect and cation balance. Soil Sci. 166, 239-249.

Rabinovitz, M.B., 1993. Modifying soil lead bioavailability by phosphate addition. Bull. Environ. Contam. Toxicol. 51, 438-444.

Sauvé, S., McBride, M.B., Hendershot, W.H., 1998. Lead phosphate solubility in water and soil suspensions. Environ. Sci. Technol. 32, 388-393.

Sauvé, S., Martinez, C.E., McBride, M.B., Hendershot, W.H., 2000. Adsorption of free lead $\left(\mathrm{Pb}^{2+}\right)$ by pedogenic oxides, ferrihydrite, and leaf compost. Soil Sci. Soc. Am. J. 64, 595-599.

Strawn, D.G., Sparks, D.L., 2000. Effect of soil organic matter on the kinetics and mechanisms of Pb(II) sorption and desorption in soil. Soil Sci. Soc. Am. J. 64, 144-156.

Tarasevich, Yu.I., Kardashova, M.B., Polyakov, V.E., 1997. Selectivity of ion exchange on clinoptilolite. KolloidZ 59 (6), 813-818 (Ru).

Tills, A.R., Alloway, B.J., 1983. The speciation of lead in soil solution of very polluted soils. Environ. Technol. Lett. 4, 529-533.

Tsadilas, C.D., 2000. Effect of soil pH on the distribution of heavy metals among soil fractions. In: Iskandar, I. (Ed.), Environment Restoration of Metals Contaminated Soils. Lewis Publishers, pp. 107-119.

Tsadilas, C.D., Dimoyiannis, D.G., Samaras, V., 1997. Effect of zeolite application and soil pH on cadmium sorption in soils. Commun. Soil Sci. Plant Anal. 28 (17-18), 1591-1602.

Tsitsishvili, G.B., Andronikashvili, T.G., Kirov, G.N., Filizova, L.D., 1985. Natural Zeolites Khimiya Publishers, Moscow. Ru.

Zyrin, N.G., Serdyukova, A.V., Sokolova, T.A., 1986. Lead sorption and speciation of the sorbed element in soils and soil constituents. Pochvovedeniye 39 (3), 47-54 (Ru). 